\title{
Peran Pendidikan Kepramukaan Sebagai Media Pembentukan Karakter Kepemimpinan Siswa Sekolah Dasar
}

\author{
1 Alfi Nur Hidayati \\ 1SDN Mendalem Tuban \\ *E-mail : mbakalfi@gmail.com
}

\begin{abstract}
Abstrak
Mendalamkan karakter kepemimpinan pada kegiatan ekstrakulikuler pramuka yang dilakukan oleh Pembina pramuka SDN Medalem I dengan tujuan agar siswa SDN Medalem I benar-benar memiliki karakter kepemimpinan yang baik dan penuh rasa tanggungjawab. Selain itu penerapan karakter kepemimpinan siswa pada ekstrakulikuler pramuka di SDN Medalem I dilakukan sejak dini agar mampu menerapkannya dalam kehidupan sehari-hari dan yang akan datang. Tujuan dari penelitian ini adalah untuk mengetahui proses implementasi dan manfaat pendidikan kepramukaan sebagai media pembentukan karakter kepemimpinan siswa di SDN Medalem I. Metode penelitian yang digunakan dalam penelitian ini adalah kualitatif deskritif yakni melihat fenomena yang terjadi dilapangan unt ${ }^{1} \mathrm{uk}$ memperoleh data dan penguraiannya secara sistematik sehingga mudah untuk dipahami. Dan teknik yang digunakan adalah observasi, komunikasi dan dokumentasi. Hasil penelitian ini menunjukan proses implementasi dan manfaat pendidikan kepramukaan sebagai media pembentukan karaker kepemimpinan siswa pembina menggunakan metode belajar sambil melakukan learning by doing tahap transinternalisasi nilai dengan memberikan contoh terlebih dahulu kemudian peserta Pramuka mengikutinya. Penerapan jelajah alam yang dilakukan setia tiga bulan sekali yang dilakukan diakhir pertemuan. Dan penerapan pada kegiatan-kegiatan dalam ekstrakuler pramuka.
\end{abstract}

Kata kunci: pramuka, media, karakter kepemimpinan

\begin{abstract}
To deepen the leadership character in the scout extracurricular activities carried out by the Scoutmasters of SDN Medalem I with the aim that students of SDN Medalem I really have good leadership characters and are full of responsibility. In addition, the application of student leadership characters in scout extracurriculars at SDN Medalem I is carried out from an early age so that they are able to apply them in everyday life and in the future. The purpose of this study was to determine the implementation process and the benefits of scouting education as a medium for the formation of student leadership characters at SDN Medalem I. The research method used in this study was descriptive qualitative, namely looking at phenomena that occur in the field to obtain data and systematically describe it so that it is easy to understand. And the technique used is observation, communication and documentation. The results of this study show the implementation process and the benefits of scouting education as a medium for forming the leadership character of students who coach using the learning method while doing the learning by doing stage of transinternalization of values by giving an example first and then the Scout participants following it. The application of nature exploration which is carried out every three months is carried out at the end of the meeting. And application to activities in extracurricular scouting.
\end{abstract}

Keywords: scouts, media, leadership character

https://doi.org/10.32665/jurmia.v1i1.191

Copyright(C 2021, Alfi Nur Hidayati This is an open-access article under the CC-BY License. 


\section{PENDAHULUAN}

Semua makhluk hidup yang ada di dunia ini manusia merupakan satu-satunya makhluk hidup yang diciptakan secara sempurna oleh Tuhan yang dianugerahi berbagai keistimewaan yang dimiliki. Salah satunya yaitu diberikannya akal yang membedakan dengan makhluk hidup yang lain. Dengan keistimewaan yang dimiliki, manusia dapat mengelola potensinya agar lebih dinamis. Agar dapat mengelola potensinya, manusia dapat mengembangkan melalui pendidikan. Hal ini sesuai dengan pendapat (Joseph, 2015) bahwa pendidikan adalah suatu usaha sadar manusia untuk mengembangkan potensi dirinya melalui proses pembelajaran dan atau cara lain yang dikenal dan diakui oleh masyarakat.

Adapun dalam Islam, pendidikan mempunyai kedudukan yang sangat penting bagi kehidupan manusia. Hal ini terdapat dalam QS. At-Taubah ayat 122:

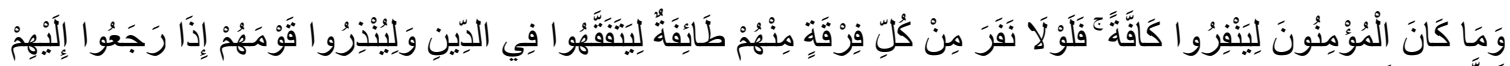

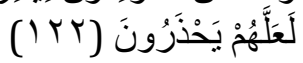

Artinya : Tidak sepatutnya bagi mukminin itu pergi semuanya (ke medan perang). mengapa tidak pergi dari tiap-tiap golongan di antara mereka beberapa orang untuk memperdalam pengetahuan mereka tentang agama dan untuk memberi peringatan kepada kaumnya apabila mereka telah kembali kepadanya, supaya mereka itu dapat menjaga dirinya. (Dept. Agama RI, 2010)

Dari ayat diatas dapat diambil kesimpulan bahwa pendidikan mempunyai peran yang penting bagi manusia dalam menjalankan kehidupan manusia bahkan Islam menganjurkan orang-orang muslim untuk selalu menuntut ilmu dimanapun berada. (Menurut Kwartir nasional, 2011) Pendidikan Kepramukaan adalah proses pendidikan yang praktis, di luar sekolah dan di luar keluarga yang dilakukan di alam terbuka dalam bentuk kegiatan yang menarik, menantang, menyenangkan, sehat, teratur, dan terarah, dengan menerapkan Prinsip Dasar Kepramukaan dan Metode Pendidikan Kepramukaan, yang sasaran akhirnya adalah terbentuknya kepribadian, watak, akhlak mulia dan memiliki kecakapan hidup.

Media apabila dipahami secara garis besar adalah manusia, materi, atau kejadian yang membangun kondisi yang membuat siswa mampu memperoleh pengetahuan, keterampilan, atau sikap. Karakter identik dengan kepribadian atau akhlak. Seiring dengan pengertian ini, ada skelompok orang yang berpendapat bahwa baik buruknya karakter manusia sudah menjadi bawaan dari lahir.. Jika pendapat ini benar, pendidikan karakter tidak ada gunanya karena tidak akan mungkin mengubah karakter orang yang sudah taken for granted. Sementara itu (Marzuki, 2015) berpendapat berbeda, yakni bahwa karakter bisa dibentuk dan diupayakan sehingga pendidikan karakter menjadi bermakna untuk membawa manusia dapat berkarakter yang baik.

Pembinaan karakter siswa di sekolah bisa dilakukan dengan tiga cara. Pertama, pendidikan karakter dilakukan secara terintegrasi ke dalam semua mata pelajaran. Kedua, pendidikan karakter juga diintegrasikan ke dalam pelaksanaan kegiatan pembinaan siswa melalui kegiatan ekstrakurikuler dan intrakurikuler. Ketiga, pendidikan karakter dilaksanakan melalui kegiatan pengelolaan semua urusan di sekolah yang melibatkan semua warga sekolah (Lysa, 2015).

\section{Kepemimpinan}

Kepemimpinan merupakan kekuatan untuk mengerakan dan memengaruhi orang. Hal ini sesuai pendapat (Sri Minarti, 2016) bahwa kepemimpinan atau leadership merupakan ilmu terapan dari ilmu-ilmu sosial, prinsip-prinsip dan rumusannya 
diharapkan dapat mendatangkan manfaat bagi kesejahteraan manusia. Kepemimpinan sebagai sebuah alat sarana atau proses untuk membujuk orang agar bersedia melakukan sesuatu secar sukarela atau suka cita.

Gerakan Pramuka adalah nama organisasi pendidikan di luar sekolah dan di luar keluarga yang menggunakan Prinsip Dasar Pendidikan Kepramukaan dan Metode Pendidikan Kepramukaan. Pendidikan Kepramukaan adalah nama kegiatan anggota Gerakan Pramuka. Pramuka adalah anggota Gerakan Pramuka yang terdiri dari anggota muda yaitu peserta didik Siaga, Penggalang, Penegak, Pandega, dan anggota dewasa yaitu Pembina Pramuka, pembantu Pembina Pramuka, Pelatih Pembina Pramuka, Pembina Profesional, Pamong Saka dan Instruktur Saka, Pimpinan Saka, Andalan, Pembantu Andalan, Anggota Mai dan Staf Karyawan Kwartir (Kwartir Nasional, 2010).

Dari perbedaan diatas, nama kegiatan anggota Gerakan Pramuka adalah Pendidikan Kepramukaan. Pengertian Pendidikan Kepramukaan adalah proses pendidikan yang praktis, di luar sekolah dan di luar keluarga yang dilakukan di alam terbuka dalam bentuk kegiatan yang menarik, menantang, menyenangkan, sehat, teratur, dan terarah, dengan menerapkan Prinsip Dasar Kepramukaan dan Metode Pendidikan Kepramukaan, yang sasaran akhirnya adalah terbentuknya kepribadian, watak, akhlak mulia dan memiliki kecakapan hidup. Pendidikan Kepramukaan merupakan proses belajar mandiri yang progresif bagi kaum muda untuk mengembangkan diri pribadi seutuhnya, meliputi aspek spiritual, emosional, sosial, intelektual dan fisik baik sebagai individu maupun sebagai anggota masyarakat.

Dari beberapa pengertian diatas, dapat disimpulkan bahwa pendidikan pramuka adalah kegiatan yang dilakukan oleh anggota gerakan pramuka yang dilakun untuk membentuk kepribadian, watak, ahlak mulia dan memiliki kecakapan hidup dengan menggunakan prinsip dasar kepramukaan dan metode pendidikan kepramukaan.

Kepemimpinan atau leadership merupakan ilmu terapan dari ilmu-ilmu sosial, prinsip rumusannya diharapkan dapat mendatangkan manfaat bagi kesejahteraan manusia. Ada banyak penegrtian yang dikemukakan oleh pakar menurut sudut pandang masing-masing. Kusnadi mengemukakan bahwa kepemimpinan tidak saja berarti pemimpin dan memengaruhi orang-orang, tapi juga pemimpin terhadap perubahan dan sumber aspirasi serta motivasi bawahan. Winardi mengartikan kepemimpinan merupakan suatu kemampuan yang melekat pada diri seseorang yang memimpin, dipengaruhi oleh berbagai macam gfaktor interern maupun iktern. Stephen P. Robbins (Badeni, 2004) mengemukakan, leadership as the ability to influence a group toward the achievement of goals bahwa kepemimpinan dapat didefinisikan sebagai kemampuan sesorang untuk memengaruhi suatu kelompok ke arah tercapainya tujuan. Menrut (Reza, 2017) Teori kepemipin meliputi:

a. Teori Otokratis dan Pemimpin Otokratis. Kepemimpinan menurut teori ini didasarkan atas perintah-perintah, paksaan, dan tindakan-tindakan yang arbiter (sebagai wasit). Pada intinya kepemimpinan dengan model seperti ini bersifat autokrat keras yakni memiliki sifat-sifat tepat, saksama, sesuai dengan prinsip namun keras dan kaku. Lembaga atau organisasi yang dipimpinnya merupakan $a$ one man show. Dengan keras dia menekankan prinsip-prinsip "business is business". Ciri khusus dari kepemimpinan seperti ini ialah:

1) Memberikan perintah-perintah yang dipaksakan, dan harus dipatuhi.

2) Menentukan policies/kebijakan untuk semua pihak, tanpa berkonsultasi dengan para anggota.

3) Tidak pernah memberikan informasi mendetail tentang rencana-rencana yang akan datang, akan tetapi hanya memberitahukan pada setiap anggota kelompoknya langkah-langkah segera yang harus mereka lakukan. 
4) Memberikan pujian atau kritik pribadi terhadap setiap anggota kelompoknya dengan inisiatif sendiri.

b. Teori Psikologis. Seorang pemimpin adalah memunculkan dan mengembangkan sistem motivasi terbaik, untuk memotivasi kesediaan bekerja dari para pengikut dan anak buah.

c. Teori Sosiologis. Kepemimpinan dianggap sebagai usaha-usaha untuk melancarkan antar-relasi dalam organisasi dan sebagai usaha untuk menyelesaikan setiap konflik organisatoris antara para pengikutnya, agar tercapai kerja sama yang baik.

d. Teori Suportif . Para pengikut harus berusaha sekuat mungkin, dan bekerja dengan penuh gairah, sedang pemimpin akan membimbing dengan sebaik-baiknya melalui kebijakan tertentu.

e. Teori Laissez Faire. Kepemimpinan Laissez Faire ditampilkan oleh seorang tokoh "ketua dewan" yang sebenarnya tidak mampu mengurus dan dia menyerahkan tanggung jawab serta pekerjaan kepada bawahan atau kepada semua anggota. Kepemimpinan semacam ini pemimpin adalah seorang "ketua" yang bertindak hanya sebagai simbol.

f. Teori Kelakuan Pribadi. Kepemimpinan jenis ini akan muncul berdasarkan kualitaskualitas pribadi atau polapola kelakuan para pemimpinnya. Teori ini menyatakan, bahwa seorang pemimpin itu tidak melakukan tindakan-tindakan yang identik sama dalam setiap situasi yang dihadapi. Pola tingkah laku pemimpin dengan ciri ini erat kaitannya dengan:

1) Bakat dan kemampuannya

2) Kondisi dan situasi yang dihadapi

3) Good will atau keinginan untuk memutuskan dan memecahkan permasalahan yang muncul

4) Derajat.

5) Supervisi dan ketajaman evaluasinya.

g. Teori Sifat Orang-Orang Besar (Traits Great Men). Teori ini memandang bahwa untuk mengidentifikasi sifat-sifat unggul seorang pemimpin dapat diketahui melalui sifat, karakter dan perilaku orang-orang besar yang sudah terbukti sukses dalam menjalankan kepemimpinannya.

h. Teori Situasi. Teori ini menjelaskan, bahwa harus terdapat daya lenting yang tinggi pada diri seorang pemimpin untuk dapat menyesuaikan diri, tuntutan situasi, lingkungan dan zaman yang terus mengalami perubahan. Sebab permasalahanpermasalahan hidup, dan saat-saat yang tidak terduga seperti adanya perang, revolusi dan lain-lain tentu penuh dengan ancaman dan bahaya.

i. Teori Humanistik/Populistik. Fungsi kepemimpinan menurut teori ini ialah mengorganisir kebebasan manusia dan memenuhi segenap kebutuhan insani, yang dapat dicapai melalui interaksi pemimpin dengan rakyat. Pada teori ini terdapat tiga variabel pokok yaitu:

1) Kepemimpinan harus memperhatikan hati nurani rakyat, dengan segenap harapan, kebutuhan dan kemampuannya.

2) Organisasi agar bisa relevan dengan kepentingan rakyat dan pemerintah.

3) Interaksi yang akrab dan harmonis antara pemerintah dan rakyat untuk membangun persatuan dan kesatuan serta hidup secara damai.

Beberapa teori kepeimpinan di atas juga sesuai yang diungkapkan (Djunawir, 2017) bahwa jenis-jenis teori kepemimpinan tersebut sebagai tolak ukur dan alat 
evaluasi untuk mengetahui jenis kepemimpinan mana yang relevan dengan konteks lembaga pendidikan Islam atau kebutuhan organisasi.

\section{Gaya Kepemimpinan}

Gaya kepemimpinan adalah suatu pola perilaku konsisten yang ditunjukan untuk diketahui pihak lain ketika berusaha memengaruhi kegiatan orang lain. Tiga tipe dasar pemimpin sebagai bentuk-bentuk proses pemecahan masalah dn mengambil keputusan adalah sebagai berikut:

a. Pemimpin otokratis.

Pemimpin otokratis memperlihatkan ciri-ciri sebagai berikut, menentukan kebijaksanaan karyawan tanpa sepengetahuan mereka. Tidak memberikan penjelasan secara terperinci tentang recana yang akan dating, tetapi ssekedar mengatakan kepada anggotanya tentang langkah-langkah yang mereka lakukan dengan segera dijalankan. Memberikan pujian kepada mereka yang selalu menurut kehendaknya dan melontarkan kritik kepada mereka yang tidak mengikuti kehendaknya, selalu jauh dengan anggota sepanjang masa.

b. Pemimpin demokratif.

Pemimpin demokratif hanya memberikan perintah setelah mengadakan musyawarah dahulu dengn anggotanya, mengetahui bahwa kebijaksanaannya hanya dapat dilakukan setelah dibicarakan dan diterima oleh anggotanya. Pemimpin tidak akan meminta anggotanya mengerjakan sesuatu tanpa terlebih dahulu memberitahukan rencana yang akan mereka lakukan. Baik atau buruk, benar atau salah adaah persoalan anggotanya dimana masing-masing ikut serta bertanggungjawab sebagai anggotanya

c. Pemimpin liberal atau laissez-faire.

Pemimpin liberal yaitu kebebasan tanpa pengendalian. Pemimpin tidak memimpin atau mengendalikan bawahan dan tidak pernah ikut serta dengan bawahannya (Sri Munarti, 2016).

\section{Karakter Kepemimpinan dan Keadilan}

Karakter yang juga perlu dibentuk pada anak adalah karakter kepemimpinan dan keadilan. Perlu diketahui terlebih dahulu bahwa pembentuk karakter kepemimpinan dan keadilan pada anak bukan berarti melatih dan mempersiapkannya menjadi seorang pemimpin. Itu artinya, anak harus diberi pemahaman bahwa ia adalah pemimpin bagi diri sendiri. Karenanya, dia harus bertanggungjawab dengan sebaikbaiknya. Menurut (Nurla Isna, 2015) ada beberapa hal yang harus dilakukan oleh orang tua yaitu menumbuhkan sikap keberanian pada diri anak, memberikan tanggungjawab dalaml rumah tangga, enumbuhkan dan menghargai kepercayaan dirinya, asah kemampuan anak dalam bersosialisasi.

Indikator-indikator karakter kepemimpinan yaitu memahami teori-teori kepemimpinan, praktek menjadi pemimpin yang adil dan bertanggung jawab, kepemimpinan yang sesuai dengan kondisi lingkungan.

\section{METODE PENELITIAN}

Penelitian ini menggunakan pendekatan kualitatif. Karena fokus penelitiannya pada Proses Pendidikan Kepramukaan sebagai media pembentukan karakter kepemimpinan siswa. Pendekatan kualitatif lebih menekankan pada analisisnya pada proses penyimpulan deduktif dan induktif serta pada analisis terhadap dinamika hubungan antar fenomena yang diamati, dengan menggunakan logika ilmiah (Syaifuddin, 2011). 
Dilihat dari segi, sifat dan maksud yang terkandung di dalamnya, yaitu Pendidikan Kepramukaan sebagai Media Pembentukan Karakter Kepemimpinan Siswa SDN 01 Medalem. Penelitian ini termasuk jenis penelitian deskriptif.

Dalam Penelitian ini penulis mengambil lokasi penelitian di SDN Medalem 01 yang berada di Desa Medalem Kecamatan Senori Kabupaten Tuban pada tanggal 18 februari 2020 dan tanggal 25 februari 2020. Jenis data yang digunakan dalam penelitian ini adalah sebuah data yang diperoleh langsung dari sumber utama informasi dengan cara peneliti datang langsung ke lokasi penelitian yaitu SDN Medalem 01. Peneliti menggunakan sumber data primer dan data sekunder.

\section{HASIL DAN PEMBAHASAN \\ 1. Implementasi Pendidikan Kepramukaan sebagai media pembentukan karakter kepemimpinan siswa.}

Implementasi adalah pelaksanaan atau penerapan dari suatu tindakan yang sudah terencana dan disusun sebelumnya. Pada penelitian yang dilakukan peneliti menemukan kegiatan yang dilakukan di SDN Medalem I yaitu proses pendidikan kepramukaan sebagai media pembentukan karakter siswa. Berdasarkan hasil penelitian yang diperoleh dari lapangan, menunjukkan bahwa tujuan diadakannya penerapan karakter kepemimpinan di kegiatan pramuka adalah untuk membentuk kepribadian yang baik, dan bertanggungjawab. terutama dalam hal keberanian, dan pembentukan karakter kepmimpinan sejak dini di jenjang sekolah dasar serta dapat mempraktekkannya dalam kehidupan sehari-hari.

SDN Medalem I menerapkan karakter kepemimpinan di mulai dari dirinya sendiri. Menerapkan karakter kepemimpinan pada anak-anak usia dini sangatlah penting karena dengan hal tersebut akan sangat menentukan kepribadian anak saat dewasa.

Pembina pramuka melakukan proses Implementasi peran pendidikan kepramukan sebagai media pembentukan karakter kepemimpinan saat kegiatan berlangsung dengan cara memberi kegiatan, memberikan contoh perbuatan yang baik serta memberi waktu siswa untuk mempraktekkan di depannya, dan adanya permainan yang berhubungan dengan peneraan karakter kepemimpinan. Peneliti menemukan kegiatan kegiatan seperti kegiatan apel pembukkan, dan penutupan pramuka yaitu dengan membagi tugas saat upacara berlangsung sesuai dengan kelompok yang di tunjuk langsung oleh pemimpin kelompok. Yang menjadi pemimpin upacara yaitu tugasnya sebagai pengarah dalam proses upacara berlangsung, dan juga anggota yang menjadi peleton putra dan putri yang bertugas menjadi pemimpin mengarahkan kelompok putra dan kelompok putri. Kemudian ada kegiatan phionering, dalam kegiatan ini seorang siswa bertanggung jawab mengarahkan anggotanya dengan cara memberikan contoh terlebih dahulu kemudian di tiru oleh para anggotanya kemudian, materi PBB(Peraturan Baris Berbaris).

Melihat cara pembina untuk melakukan Implementasi pendidikan kepramukaan sebagai media pembentukan karakter kepemimpinan siswa, peneliti dapat mengetahui bahwa pembina menggunakan tahap proses Implementasi. Yakni tahap transinternalisasi nilai dengan memberikan contoh terlebih dahulu dengan memberikan materi dan arahan memimpin dengan benar kemudian peserta pramuka mengikutinya atau bisa disebut dengan belajar sambil melakukan (learning by doing). Cara yang dilakukan pembina untuk melakukan proses implementasi karakter kepemimpinan sesuai dengan teori pendidikan progrensif oleh (John dewey, 2012). 
Adapun dengan kegiatan-kegiatan pramuka yang ditemukan peneliti ketika melakukan penelitian di lokasi adalah apel pembukaan dan penutupan, kegiatan jelajah alam yang meliputi permainan-permaina yang didalamnya terdapat karakter kepemimpinannya dan kegiatan-kegiatan berkelompok seperti PBB dan phionering. Kegiatan tersebut dilakukan pada peserta golongan penggalang karena pada saat itu pembina yang bisa hadir hanya satu dari pembina penggalang, sehingga yang diaktifkan kegiatan pramuka adalah golongan penggalang saja sedangkan untuk golongan siaga sementara diliburkan.

2. Manfaat pendidikan kepramukaan sebagai media pembentukan karakter kepemimpinan siswa.

Manfaat adalah sesuatu yang menjadi nilai guna dalam suatu hal. Didalam pendidikan kepramukaan bukan hanya terdapat kegiataan atau materi yang monoton saja akan tetapi kegiatan tersebut mempunyai banyak sekali manfaat dan giatan tersebut berbentuk permainan didalamnya.

Diantara manfaat pembentukan karakter kepemimpinan di dalam kegiatan pramuka di SDN Medalem I sebagai berikut:

\section{Mampu mengenal diri sendiri.}

Proses implementasi yang telah dilakukan pembina pramuka kepada peserta pramuka di SDN Medalem I terdalat manfaat mampu mengenal diri sendiri disini siswa dilatih mengenal dan melatih memimpin dirinya sendiri yaitu dari kedisiplinan siswa. Disiplin merupakan pokok dasar dalam meningkatkan kemampuan bertindak, berfikir dan bekerja secara aktif dan kreatif melalui proses latihan belajar.displin juga merupakan suatu kepatuhan dari anggota organisasi (keluarga, sekolah, lingkungan dan sebagainya) terdapat peraturan-peraturan yang telah ditetapkan untuk menyesuaikan diri agar menjadi sesuatu kebiasaan pada individu sehingga menimbulkan keadaan tertib (Imam, 2016).

Dalam Pramuka, perihal waktu merupakan sesuatu yang sangat penting karena menetukan seseorang itu akan mendapatkan keuntungan atau sebaliknya. Setiap orang harus bisa menggunakan waktu sebaik-baiknya, karena waktu tidak bisa diputar kembali.

Pembina membiasakan kepada para anggota pramuka untuk bisa mengendalikan diri sendiri melalui kedisiplinannya dalam kegiatan pramuka seperti tidak terlambat berangkat sekolah dan hadir tepat waktu. Kebiasaan tersebut merupakan hal yang penting untuk mewujudkan karakter kepemimpinan mulai dari memimpin diri sendiri. Pembina membuat peraturan-peraturan dalam penerapan kegiatan pramuka, diantaranya adalah hadir tepat waktu dalam kegiatan pramuka. Setiap anak yang tidak displin akan diberi sanksi atau hukuman yaitu memimpin yel-yel di depan para anggota yang lain guna melatih anak untuk percaya diri dihadapan orang lain.

Dengan usaha yang telah dilakukan peran pendidikan kepramukaan sebagai media pembentukan karakter kepemimpinan pada peserta pramuka terutama dalam pemanfaatannya diharapkan para siswa menjadi seorang yang berani, dan disiplin. Berani disini bukan berarti berani dalam hal yang negatif akan tetapi berani dalam hal positif.

\section{Memiliki rasa tanggung jawab.}

Tanggung jawab adalah rasa sadar atau menyadari suatu hal dari akibat yang telah dilakukan baik hal baik atau buruk. Dari kegiatan pramuka yang telah dilaksanakan di SDN Medalem I dalam hal rasa tanggung jawabnya adalah memberikan kepastian atau keputusan bersama yang dilakukan dalam proses pengambilan resiko yang akan timbul setelah hal itu dilakukan. 
Hasil yang ditemukan oleh peneliti dalam observasi dilapangan adalah yaitu pada proses pembuatan karya seni yang mana karya seni seorang ketua kelompok harus bisa mengarahkan para anggotanya dengan rasa penuh tangung jawab. Manfaat dari pembuatan karya ini sangatlah banyak diantaranya adalah membuat para anggota kelompok bekerja bersama.

Rasa tanggung jawab dari seorang pemimpin merupakan hal sangat perlu ditekankan karena rasa tanggung jawab adalah salah satu macam ciri-ciri pemimpin yang ideal.

Hal ini sesuai dengan dasa darma yang ke-9 yang berbunyi "Bertanggung Jawab dan dapat dipercaya". Dasa darma adalah ketentuan moral. Dasa darma yang berarti sepuluh tuntunan tingkah laku adalah sarana untuk melaksanakan satya (janji, ikrar, ungkapan kata hati).

Peneliti juga mendapatkan temuan dalam observasi dalam penerapan pendidikan kepramukaan dalam pembentukan karakter kepmimpinan yaitu pada saat ketua kelompok mengabsen para anggotanya dan mencatat siapa yang tidak hadir dalam latihan pramuka tersebut dan siapa yang terlambat hadir dalam latihan pramuka. Yang kemudian catatan tersebut akan diberikan oleh pembina pramuka.

\section{Pandai bersosialisasi}

Sosialisasi adalah proses adaptasi dengan lingkungan sekitar. Hasil yang ditemukan peneliti melalui wawancara dengan pembina dan observasi di SDN Medalem I yakni seperti kegiatan talitemali phionering terlihat seorang ketua kelompok memberikan arahan sesuai arahan dari pembina kepada anggotanya dalam proses talitemali yang sesuai dengan tatacara dan arahan yang benar.

Disini siswa dituntut untuk menjadi kelompok yang bisa bekerja sama dengan temannya dan tugas seorang ketua kelompok adalah memberikan keputusan yang baik dengan penuh rasa tanggung jawab. Gaya kepemimpinan ini bisa disebut dengan gaya kepemimpinan demokratif yang mana seorang pemimpin memberikan perintah setelah pemimpin memberikan cara-cara yang sesuai dengan arahan pembina.

Seorang pemimpin harus memberikan pengaruh yang potif terhadap para anggotanya dengan memberikan arahan yang positif. Positif ini berarti mengarahkan dengan baik.

Karakter kebaikan dalam diri seeseorang itu bukan merupakan sesuatu yang datang dengan tiba-tiba langsung dalam diri, akan tetapi terbangunnya melalui proses pembiasaan yang panjang. Hal ini sama dengan hanya yang dilakukan pembina dalam pembentukan karakter yaitu dengan pembiasaan, mulai dari pembiasaan seorang anggota pramuka khususnya seorang ketua kelompok untuk menjadi pemimpin yang baik. Hal ini sesuai dengan pendapat (Sri minarti, 2016) bahwa melalui pengalaman dari sejak dini. Hal ini sesuai dengan yang di utarakan oleh fiits, bahwa konsep diri berpengaruh kuat terhadap tingkah laku (akan menjadi karakter bila tingkah laku tersebut menjadi kebiasaan).

\section{KESIMPULAN DAN SARAN}

Berdasarkan uraian penjelasan dan analisa di atas sebagai hasil penelitian yang dilakukan peneliti di SDN Medalem I yang berkenaan dengan Peran Pendidikan Kepramukaan Sebagai Media Pendia Pembentukan Karakter Kepemimpinan di SDN Medalem I, maka penulis mengambil beberapa kesimpulan sebagai berikut:

1. Implementasi pendidikan kepramukkan sebagai media pembentukan karakter kepemimpinan siswa, Pembina menggunakan metode belajar sambil melakukan 
(learning by doing) tahap transinternalisasi nilai dengan memberikan contoh terlebih dahulu kemudian peserta Pramuka mengikutinya. Penerapan jelajah alam yang dilakukan setia tiga bulan sekali yang dilakukan diahir pertemuan.

a. Adapun kegiatan-kegiatan dalam kegiatan ekstrakurikuler Pramuka yang terdapat implementasi karakter kepemimpinan di SDN Medalem I adalah :

1) Upacara pembukaan dan penutupan kegiatan latihan pramuka : memimpin upacara saat bertugas sesuai jadwal yang telah ditetapkan.

2) PBB (Peraturan Baris Berbaris) : Mengarahkan anggotanya dalam mengatur barisan sesuai dengan arahan pembina.

3) Phionering : memimpin dengan mengarahkan sesuai dari arahan Pembina dalam menyusun talitemali membuat tandu.

4) Permainan : permainan Blind Walk, pemimpin hartus memikirkan strategi apa yang dilakukan agar anggotanya dapat sampai ke garis finish terlebih dahulu.

2. Manfaat penerapan karakter kepemimpinan dalam dirisiswa sebagai berikut:

a. Mampu mengenal diri sendiri : siswa memimpin dimulai dari dirinya sendiri. Memimpin diri dengan rasa disiplin saat berangkat pramuka tepat waktu.

b. Memiliki rasa tanggung jawab : pembuatan karya seni.pemimpin mengarahkan denganrasa tanggung jawab dalam mengarahkan anggotanya dalam memutuskan sebuah karya seni yang akan dibuat.

c. Pandai bersosialisasi : kegiatan phionering talitemali. Pemimpin memberikan arahan sesuai yang dijelaskan oleh pembina mensosialisasikan sebuah materi talitemali yang telah diajarkan pembina kepada anggotanya

Kemudian saran dari hasil penelitian ini adalah pada saat kegiatan Pramuka berlangsung sebaiknya seluruh siswa benar-benar memperhatikan Pembina, Sehingga seluruh siswa benar-benar memperoleh hasil implementasi yang dilakukan. Seharusnya Pembina memiliki jadwal tugas memimpin setiap kegiatan ektrakulikuler pramuka, agar Pembina lebih mudah mengetahui dan tau sebenar-benarnya tugas pada setiap pertemuan.

\section{REFERENSI}

Arsyad, Azhar. (2017). Media pembelajaran. Jakarta: Rajawali Pers.

Aunillah. Nurla Isna. (2015). Membentuk Karakter Anak Sejak Janin. Yokyakarta: flashBooks.

Bungin, Burhan. (2010). Metodologi Penelitian Kualitatif. Jakarta: PT. Raja Grafindo Persada.

Departemen Agama RI. (2010). Al-Qur'an dan terjemahnya. Bandung: Diponegoro.

Karo-Karo S, Isran Rasyid. (2018). Manfaat media dalam pembelajaran. Dosen Tetap Jurusan Pendidikan Matematika FITK UIN-SU Medan, Vol. VII, No. 1, Januari Juni 2018.

Kwartir Nasional. (2011). Kursus Pembina Pramuka Mahir Tingkat Dasar, Jakarta: Penerbit Kwartir Nasional.

Mahnun, Nunu. (2012). Media Pembelajaran. Kajian terhadap Langkah-langkah Pemilihan Media dan Implementasinya. Jurnal Pemikiran Islam; Vol. 37, No. I.

Marzuki dan Hapsari, Lysa. (2015). Pembentukan karakter siswa melalui kegiatan kepramukaan. Fakultas Ilmu Sosial Universitas Negeri Yogyakarta, Nomer V. 
Mbulu, Joseph, dkk. (2005). Pengantar Pendidikan. Malang: Laboratorium Teknologi Pendidikan.

Minarti, Sri. (2016). Manajemen Diri Islami. Yokyakarta; Interpena.

Moleong, Lexy. (2016). Metodologi Penelitian Kualitatif. Bandung: Remaja Rosda Karya.

Muhlisin, Moh imam. (2016). implementasi kegiatan pramuka dalam membentuk karakter disiplin siswa anggota gerakan pramuka di sekolah dasar negri sukun tiga malang. Universitas Negri Malang.

Salim, Man. (2017). Pedoman Lengkap Pramuka. Semarang: Syalmahat Publishing.

Suardi , Reza hafikar. (2017). Peran Pemimpin dalam Meningkatkan Kinerja Pegawai (Studi Kasus Pkp2a II Lembaga Administrasi Negara (LAN) Kota Makassar), Universitas Hasanuddin, Fakultas Ilmu Sosial Dan Ilmu Politik departemen Ilmu Administrasi Program Studi Administrasi Negara.

Sugiyono, (2013). Metode Penelitian Pendidikan. Bandung: Alfa Beta.

Sujarwin , Wirata. (2014). Metodologi penelitian. Yogyakarta; PUSTAKABARUPRES.

Sukardi, (2017). Metodelogi penelitian pendidikan. Jakarta: bumi aksara.

Suttrisno, S. (2021). Pengaruh Pemanfaatan Alat Peraga Ips Terhadap Kinerja Guru Sekolah Dasar. Jurnal Ilmiah Pendidikan Dasar, 8 (1), 77-90.

Syafar, Djunawir. (2017). Teori Kepemimpinan dalam Lembaga Pendidikan Islam, Volume 5, Nomor I.

Tombo ati online. (2016). Pengertian dan tujuan tentang leraning by doing. Moeloes.blogspot.com 